\title{
KONSISTENSI PENERAPAN DOKTRIN PIERCING THE CORPORATE VEIL PADA PERSEROAN TERBATAS DI INDONESIA
}

\author{
Sulistiowati dan Veri Antoni \\ Fakultas Hukum Universitas Gajah Mada Yogyakarta \\ Email: sulistyowati.fhugm@gmail.com
}

\begin{abstract}
This research aims to analyze the importance and the application of piercing the corporate veil in the legal policy of limited liability company. This research is included into juridical and normative research, utilizing library research to obtain secondary data. Such data deriving from legal principles, statutes, and literature are fither analyzed in a qualitative method, producing descriptive-analytical output. In addition, a study is conducted to compare the application of piercing the corporate veil in various jurisdictions. The result firstly shows the reasons that the doctrine of piercing the corporate veil is important in the legal policy of limited liability company: (1) to provide a legal certainty; (2) the existence of piercing the corporate veil in statutes will provide strict sanctions, hence achieving a deterrent effect; (3) to reduce litigation costs; (4) to encourage the implementation of piercing the corporate veil. Secondly, an expansion of regulation regarding piercing the corporate veil is found from the commercial code to Law Number 1 of 1995 and Law Number 40 of 2007.
\end{abstract}

Key words: legal entity, limited liability company, piercing the corporate veil.

\begin{abstract}
Abstrak
Penelitian ini bertujuan untuk mengetahui arti penting dan penerapan piercing the corporate veil dalam peraturan perundang-undangan di bidang Perseroan Terbatas. Penelitian ini merupakan penelitian yuridis normatif yang mendasarkan pada penelitian kepustakaan guna memperoleh data sekunder. Data yang diperoleh dari asas-asas hukum, peraturan-peraturan, dan buku-buku yang dianalisis dengan menggunakan metode kualitatif. Penelitian kualitatif ini menghasilkan data deskriptif-analitis. Selain itu, dilakukan juga studi untuk membandingkan penggunaan piercing the corporate veil di berbagai negara. Hasil penelitian menunjukkan bahwa pertama, arti penting pengaturan piercing the corporate veil dalam peraturan perundang-undangan di bidang perseroan terbatas adalah karena: (1) untuk memberikan kepastian hukum; (2) keberadaan piercing the corporate veil di undang-undang akan berimplikasi pada sanksi yang tegas sehingga efek jera dapat tercapai; (3) untuk menekan biaya litigasi; (4) untuk memotivasi penerapan piercing the corporate veil. Kedua, prinsip piercing the corporate veil di dalam perundang-undangan di bidang P.T di perluas dari KUHD sampai dengan UU Nomor 1 Tahun 1995 dan UU Nomor 40 Tahun 2007.
\end{abstract}

Kata kunci: badan hukum, perseroan terbatas, piercing the corporate veil.

\section{A. Pendahuluan}

Sejak pertama kali diartikulasikan pada tahun 1897 dalam putusan pengadilan Inggris Salomon $\checkmark$ Salomon,limited liability merupakan prinsip yang jamak berlaku di dunia modern bahwa pemegang saham dalam suatu perseroan terbatas tidak dapat dimintai pertanggungjawaban melebihi jumlah andil modal mereka (Thomas K.Cheng, 2011:412). Prinsip limited liability menawarkan perlindungan dan kepastian hukum kepada investor dan pada gilirannya akan memotivasi investor untuk terus melakukan dan mengembangkan kegiatan ekonomi dan bisnis. Apabila kreditur suatu perseroan diperkenankan untuk menjangkau harta pribadi investor dalam hal terjadi kegagalan bisnis, maka investor tentu akan ragu-ragu untuk berinvestasi (Robert Thompson, 1991:76).

Pertanggungjawaban yang tidak terbatas (unlimited liability) merupakan disinsentif bagi investor. Bila tanggungjawab investor tidak dibatasi sejumlah andil yang dikontribusikannya, maka konsekuensinya investasi skala kecil saja sudah akan dapat membebani pemegang saham dengan utang korporasi yang besar. Investor 
akan terpaksa mengeluarkan uang, waktu, dan tenaga untuk memonitor kinerja perusahaan serta mengawasi investor lainnya. Selain itu, akan muncul kecenderungan investor untuk menanamkan modal di beberapa perusahaan saja untuk mengurangi risiko kehilangan harta pribadi dari banyak perusahaan sekaligus (Helen Anderson, 2009: 333-367).

Akan tetapi, apabila diterapkan secara kaku, prinsip pembatasan tanggungjawab ini dapat menimbulkan ketidakadilan. Pada kenyatannya perlindungan hukum ini telah menimbulkan moral hazard di mana pemegang saham suatu perseroan menyalahgunakan prinsip pembatasan tanggungjawab untuk kepentingan pribadi mereka. Misalnya dengan mendirikan perseroan yang pada hakikatnya hanya bertindak sebagai buffer atau perisai agar seorang pemegang saham dapat melakukan perbuatan melawan hukum, menghindari kewajiban hukum (Gilford Motor V Horne:1933), atau melakukan kegiatan bisnis berisiko tinggi tanpa perlu khawatir akan dimintakan pertanggungjawaban pribadi.

Menanggapi kekhawatiran bahwa penerapan prinsip pembatasan tanggungjawab malah akan membawa ketidakadilan, muncul doktrin yang dijuluki piercing the corporate veil (menyingkap tabir perusahaan, "PCV"). Embrio pertama doktrin ini sudah tersemai dalam beberapa kasus lawas di negara Inggris, yaitu dalam Apthorpe $v$ Peter Schoenhofen Brewing (1899:245), dan gilford Motor v Horne (1933). Di kalangan akademisi, Wormser (1912) merupakan salah satu sarjana pertama yang menyinggung doktrin piercing the veil.

Baik putusan pengadilan (Parbulk II AS v PT Humpus Internoda Transportasi Tbk, 2011:43) maupun pendapat para sarjana (Anderson, 2009:342, Thomas Cheng, 2011, Davies, 2008:208-209, Gavert,1997, Bradley Reed, 2006:1649). pada umumnya menempatkan piercing the corporate veil sebagai suatu 'doktrin' yang membuat pengecualian terhadap suatu 'prinsip umum'. Artinya, prinsip umum di mana tanggungjawab pengurus perusahaan dibatasi kepada jumlah andilnya dapat disimpangi oleh doktrin PCV dengan cara membuat tanggungjawab pengurus perusahaan tidak lagi terbatas (Bradley Reed, 2006:1643-1675).

Saat ini, doktrin PCV telah dikenal secara luas - baik melalui yurisprudensi maupun undang-undang - di berbagai negara ((Bradley Reed, 2006). Di Indonesia sendiri, baik prinsip pembatasan tanggungjawab maupun doktrin PCV telah diintrodusir dalam UU Perseroan Terbatas 1995, yang kemudian dipertahankan dalam UU Perseroan Terbatas 2007, yang mencabut dan menggantikan UU Perseroan Terbatas 1995. Adapun di Amerika Serikat, hanya doktrin pembatasan tanggungjawab yang dinyatakan secara tegas dalam undang-undang. Doktrin PCV tidak diinkorporasikan sebagai pengecualian yang dinyatakan secara tertulis dalam undangundang di sebagian besar negara bagian Amerika Serikat (Jonathan A. Marcantel, 2010:191-230, Robert Thompson, 1991:1041). Doktrin ini telah berkembang secara cepat di AS. Dalam praktik pengadilan, tiga tes untuk menentukan keberlakuan doktrin PCV telah dikembangkan, yakni tes alter ego, tes instrumentality, dan tes ketidakadilan.Bahkan, mungkin karena bersemangatnya hakim-hakim untuk menciptakan kepastian hukum dalam doktrin PCV, banyak negara bagian yang menciptakan tes-tes dan faktor-faktor lain untuk dipertimbangkan dalam kasus PCV. Dalam Associated Vendors, Inc v Oakland Meat co., misalnya, Pengadilan Tinggi California menetapkan tidak kurang dari 20 faktor yang dapat digunakan pengadilan untuk menjustifikasi suatu putusan PCV.

Di Indonesia, dalam Undang-undang Perseroan Terbatas 2007, pemegang saham perusahaan dapat dibebani tanggungjawab sampai ke harta pribadi mereka apabila:

1. Persyaratan perseroan sebagai badan hukum belum dipenuhi;

2. Pemegang saham dengan itikad buruk memanfaatkan perseroan untuk kepentingan pribadi;

3. Pemegang saham terlibat dalam perbuatan melawan hukum yang dilakukan oleh perseroan; atau

4. Pemegang saham menyebabkan kekayaan perseroan tidak cukup untuk melunasi utang perseroan.

Dewan direksi dan komisaris juga dapat dimintakan pertanggungjawaban pribadi dalam hal mereka tidak melaksanakan fiduciary duty kepada perseroan dan lalai dalam menghitung dokumen tahunan. Selain itu, apabila perusahaan pailit akibat kelalaiandireksi, makadireksi bertanggungjawab secara pribadi.

Berdasarkan uraian di atas, dapat dirumuskan permasalahan sebagai berikut:

1. Apakah arti penting piercing the corporate veilperlu diatur dalam peraturan perundangundangan di bidang Perseroan Terbatas? 
2. Bagaimanakah penerapan piercing the corporate veil dalam peraturan perundangundangan di bidang Perseroan Terbatas di Indonesia?

\section{B. Metode Penelitian}

Penelitian ini merupakan penelitian yuridis normatif, yaitu penelitian yang memfokuskan kajian pada penelitian data sekunder untuk mendapat berbagai data mengenai konsep dasar doktrin, dan norma hukum; pelaksanaan doktrin PCV dan konsistensinya; serta perbandingan pelaksanaan doktrin PCV di Indonesia dengan yurisdiksi negaranegara lain yang doktrin PCV-nya sudah mapan, Dalam kaitannya dengan penelitian normatif, akan digunakan tiga jenis pendekatan yakni pendekatan konsep, pendekatan kasus, dan pendekatan undang-undang. Dengan demikian, penelitian ini diharapkan akan mampu memberikan hasil yang komprehensif yang mampu mengawinkan aspek teoretis dan praktis.

\section{Hasil Penelitian dan Pembahasan}

1. Arti Penting Pengaturan PCV dalam Undang-Undang PT Insentif untuk Berinvestasi dan Memberi Kredit Modal

Suatu perseroan adalah entitas yang berbeda dan berdiri sendiri terpisah dari pemegang sahamnya. Pemegang saham suatu perseroan tidak memiliki tanggungjawab terhadap kreditur utang perseroan. Prinsip pemisahan tanggungjawab perusahaan dengan pemegang saham ini telah dianut sejak putusan Solomon. Doktrin PCV muncul sebagai respon terhadap rigiditas prinsip ini yang tidak memperkenankan pemegang saham dimintai pertanggungjawaban atas utang perseroan melebihi jumlah investasinya (Strasser A. Kurt, 2005: Vol. 37).

Akan tetapi di sisi lain, doktrin PCV yang menghapuskan pertanggungjawaban terbatas berpotensi membawa guncangan terhadap insentif untuk berusaha. Ide dasar tanggungjawab pemegang saham dibatasi adalah untuk mendorong investasi dan akumulasi modal. Pemegang saham yang memiliki tanggungjawab tidak terbatas akan berusaha mengumpulkan informasi sebanyakbanyaknya mengenai keadaan finansial perseroan, mengawasi sesama pemegang saham lain agar tidak pergi meninggalkannya menanggung beban utang perseroan sendiri, dan cenderung gemar mengintervensi proses pengambilan keputusan dalam tubuh perseroan agar perilaku yang terlalu berisiko dapat diawasi (Helen Anderson, 2009: 333367). Perilaku seperti ini memakan energi, biaya, dan waktu serta berpotensi melahirkan masalah keengganan berinvestasi di bidang usaha yang berisiko tinggi. Dengan kata lain, pertanggungjawaban tidak terbatas adalah bentuk disinsentif bagi keinginan investor menanam modal.

Tidak hanya terhadap investor, derajat pemisahan tanggungjawab juga berpengaruh terhadap keinginan kreditor untuk memberikan pinjaman modal. Apabila pemegang saham tidak ikut bertanggungjawab atas utang perusahaan, kreditor bisa jadi tidak termotivasi untuk memberikan kredit modal dalam jumlah yang relatif tinggi karena dalam hal terjadi gagal bayar, kreditor yang bersangkutan tidak dapat memintakan pertanggungjawaban pribadi dari pemegang saham perseroan. Walaupun kreditor sebenarnya dapat melindungi dirinya sendiri dari risiko gagal bayar - misalnya dengan meminta jaminan utang atau dengan menyisipkan ketentuan-ketentuan khusus dalam transaksi bisnis seperti larangan bagi perseroan untuk memecah atau membebani aset dengan hak tanggungan - pada kenyataannya: (1) analisis risiko gagal bayar dapat tidak sebanding dengan nilai piutang, (2) tidak semua kreditor memiliki kapasitas untuk menganalisis besaran risiko gagal bayar mitra bisnisnya, dan (3) tidak semua kreditor punya posisi tawar yang cukup kuat untuk melindungi kepentingannya sendiri (Helen Anderson, 2009: 333-367).

a. Perlindungan Hak-Hak Kreditur

Default rule tanggungjawab terbatas sebenarnya berpotensi menyalahi kepentingan kreditor. Pada titik ini, aturan PCV berusaha menyeimbangkan kembali kepentingan kreditor dengan memberikan kesempatan bagi kreditor yang hak-haknya dirugikan oleh perbuatan suatu perusahaan untuk mengajukan gugatan sampai ke harta pribadi pemegang saham.

Dua contoh perkara di mana kepentingan kreditor dapat terganggu sebagai akibat dari penyalahgunaan 
prinsip pemisahan tanggungjawab perusahaan adalah perkara penipuan dan pernyataan yang menyesatkan serta perkara pelucutan aset perusahaan.

b. Perkara Penipuan dan Pernyataan yang Menyesatkan.

Menurut Cheng, arti penting pengaturan PCV dalam perkara penipuan dan pernyataan menyesatkan (fraud and misrepresentation case) tidak bersandar pada perspektif biaya transaksi (transaction cost) seperti yang dikatakan Posner,melainkan pada argumen estoppel (Thomas K. Cheng, 2011: Vol 34:329-412 dan vol. 2: 360-361). Menurut Posner, PCV dapat diterapkan pada perkara penipuan dan pernyataan menyesatkan karena menyebabkan kreditor melakukan monitoring dengan besaran biaya sosial yang sebenarnya tidak perlu (Richard Posner, 1976: Vol. 499: 520-521). Pendapat Posner ditentang oleh Cheng karena apabila PCV diterapkan karena pemegang saham mengeluarkan pernyataan yang menyesatkan, si pemegang saham cukup melakukan penipuan dan pernyataan yang menyesatkan tersebut secara lebih licin dan canggih lagi sehingga tidak dapat dideteksi oleh kreditor, misalnya dengan membuat rekening di negara tax haven. Jadi, penerapan tanggungjawab personal kepada pemegang saham tidak akan pernah menghapus praktik penipuan atau pernyataan menyesatkan, melainkan hanya akan membuat pemegang saham lebih kreatif lagi mencari siasat.

Menurut Cheng, alasan PCV harus diterapkan pada pemegang saham yang telah melakukan penipuan atau pernyataan yang menyesatkan adalah karena ketika pemegang saham memberikan pernyataan yang tidak benar atau palsu lalu si kreditor secara tulus bersandar pada pernyataan itu, maka si pemegang saham terhalang untuk menyangkal pernyataannya (doktrin estoppel). Jadi, sebagai hukuman karena telah menyangkal pernyataannya, maka pertanggungjawaban pribadi dapat diterapkan kepada pemegang saham yang mengeluarkan pernyataan tidak benar tersebut. c. Perkara Pelucutan Aset Perusahaan.

Pelucutan aset perusahaan adalah tindakan pemegang saham mengurangi aset perusahaan dengan cara membagikan dividen dalam jumlah yang terlalu besar, menaikkan gaji dewan direksi, atau cara lain. Sebagai akibatnya, perusahaan menjadi insolven dan tidak dapat membayar kreditornya.

Hakim Amerika dan hakim Inggris memiliki pendekatan tes yang berbeda dalam menentukan apakah PCV dapat diterapkan terhadap perkara pelucutan aset perusahaan. Pelucutan aset perusahaan pada dasarnya adalah tindakan mengelak (evade) dari kewajiban hukum yang berlaku. Hakim Inggris cenderung kolot dalam mempertahankan prinsip pemisahan tanggungjawab; mereka enggan untuk menerapkan PCV kepada perusahaan yang bona fide (Thomas K. Cheng, 2011:366), dan hanya mau menyibak tabir perusahaan apabila perusahaan tersebut secara aktif berusaha mengelakkan kewajiban hukumnya padahal kewajiban tersebut telah ada pada saat perusaan didirikan. Namun apabila perusahaan tersebut hanya menghindar dari kewajiban hukum (jadi, kewajiban hukumnya belum ada pada saat perusahaan didirikan), maka hakim Inggris akan cenderung memilih untuk mempertahankan pemisahan tanggungjawab perusahaan tersebut (Thomas K. Cheng, 2011:366, China Ocean Shipping V Mitrans Shipping, 1995:3 HKC 123,127). Jadi, hakim Inggris tidak menengok pada aspek hakhak kreditor, melainkan hanya menengok pada waktu pendirian perusahaan vis-àvis kala aset perusahaan dilucuti.

Berbeda dengan pendekatan hakim Inggris, hakim Amerika lebih memerhatikan hak-hak kreditor karena legal test yang digunakan untuk menentukan apakah PCV dapat diterapkan dalam perkara pelucutan aset perusahaan adalah realitas ekonomi dan bisnis (Thomas K. Cheng, 2011: 369). Secara sederhana dapat dikatakan bahwa apabila hakim Amerika menemukan seorang pemegang saham secara sengaja melukai kepentingan kreditor (jadi penekanan pada aspek 
keadilan dan kebijakan) maka hakim tersebut akan cenderung berkenan menyibak tirai perusahaan dan membuat pemegang saham bertanggungjawab secara pribadi atas kerugian.

d. Penegakan Ketertiban Umum dan Keadilan

Salah satu arti penting pengaturan PCV dalam hukum positif adalah untuk mewujudkan ketertiban umum dan keadilan. Implikasi dari tindakan seorang pemegang saham yang kontraproduktif terhadap tujuan undang-undang dapat dijadikan dasar untuk mengabaikan prinsip pemisahan tanggungjawab. Dengan kata lain, apabila perlindungan yang diberikan undang-undang kepada investor berupa struktur perusahaan dan pemisahan tanggungjawab menimbulkan kerugian bagi ketertiban umum, maka perlindungan tersebut tidak selayaknya ditegakkan.

Ada ketegangan atau tarik-menarik antara prinsip pemisahan tanggungjawab dengan doktrin PCV. Sebagaimana telah dibahas di bagian awal penelitian ini, salah satu alasan dipisahkannya tanggungjawab perusahaan dari tanggungjawab pemegang saham/ direksi adalah untuk mendorong kegiatan penanaman modal dan pengembangan usaha. Apabila tanggungjawab pemegang saham diinsulasi dari tanggungjawab perusahaan, maka risk-taking behaviour akan berkembang dengan subur (rainham chemical Works $v$ Belvedere Fish guano [1921] 2 AC 467). Akan tetapi, doktrin PCV berusaha untuk merestorasi atau mengembalikan keseimbangan hak dan kewajiban yang terganggu dalam hal prinsip pemisahan tanggungjawab menimbulkan kerugian bagi ketertiban umum.

e. Pengaturan PCV: 'Judge-Made Law'Atau 'Statute Law'?

Sebagaimana telah dijabarkan di bab Tinjauan Pustaka, piercing the corporate veil ("PCV") merupakan doktrin di mana status perseroan terbatas sebagai suatu entitas hukum yang mandiri terpisah dari pemegang sahamnya dapat dikesampingkan sehingga para pemegang saham pun dapat ikut bertanggungjawab atas utang dan liabilitas perseroan. Setelah sebelumnya analisis arti penting PCV telah cukup dibahas, bagian ini akan menganalisis wadah pengaturan PCV. Sejak pertama kali muncul dalam khazanah hukum perseroan melalui putusan pengadilan Inggris Apthorpe $v$ Peter Schoenhofen Brewing (1899, 15 T.L.R. 245 (A.C.).). dan gilford Motor v Horne (1933, Ch), doktrin PCV juga telah diwujudkan dalam bentuk yurisprudensi (judge-made law) maupun peraturan perundang-undangan tertulis (statute law) di beberapa negara. Pertanyaan yang timbul adalah: apakah yang menyebabkan suatu negara memilih untuk menginkorporasikan doktrin PCV ke dalam peraturan perundangundangan tertulis (misalnya Indonesia (Sulistiowati, 2010:98), Cina (Bradley C. Reed,2006: Vol. 39: 1643-1675), dan Ethiopia (Endalwe Lijalem enyew, 2012: Vol. 6, 1: 77-114) atau memilih untuk membiarkan doktrin ini tumbuh dalam yurisprudensi (misalnya Amerika (Thomas K. Cheng, 2011: 331), Inggris Thomas K. Cheng, 2011: 331), Australia (Helen Anderson, 2009:360), dan Hong Kong (Thomas K. Cheng, 2011: 331:207-234)?. Penelitian ini menengok kepada dua yurisdiksi hukum: Cina dan Amerika untuk menjawab pertanyaan di atas. Kedua negara adidaya ini memilih pendekatan yang berbeda dalam mengatur PCV: Cina memilih pengaturan melalui hukum tertulis, sementara Amerika memilih pengaturan melalui yurisprudensi. Adapun pertanyaan yang akan dijawab melalui artikel ini adalah: mengapa pengaturan doktrin PCV di common law malah menghasilkan ratusan bahkan ribuan sumber hukum yang tidak terharmonisasi (Helen Anderson, 2009: 360)? Mengapa doktrin PCV di Cina dibentuk oleh peraturan perundang-undangan tertulis alih-alih dalam common law?

f. Aturan PCV dalam Yurisprudensi Hukum PT Amerika

Amerika dikenal memiliki yurisprudensi dan literatur PCV yang sangat kaya. Survey Thompson pada tahun 1990 - 1991 menunjukkan ada paling tidak 2.000 perkara PCV di 
Amerika Serikat (Robert B. Thompson, 1991: 207-234) sehingga bisa dikatakan kiblat ilmu pengetahuan dunia terkait PCV adalah Amerika. Berdasarkan faktafakta tersebut kami memilih Amerika Serikat sebagai pembanding bagi analisis mengenai pengaturan PCV di Cina.

Doktrin PCV di Amerika Serikat eksis sebagai suatu instrumen pemulihan hak yang diciptakan secara yudisial. Artinya, walaupun setiap negara bagian Amerika mengakui prinsip tanggungjawab terbatas melalui hukum positif peraturan perundang-undangan di bidang perseroan, doktrin PCV tidak pernah dikristalkan dalam suatu aturan hukum positif (Jonathan A. Marcantel, 2010:195). Bila dideskripsikan, doktrin ini lebih mirip suatu konsep dalam ranah keadilan dan kepatutan (Kenneth B Watt, 1993), alih-alih suatu norma hukum tertulis.

Perkembangan doktrin PCV di Amerika sangat pesat, sebagaimana terlihat dari banyaknya legal test, faktor, upaya kategorisasi kasus PCV yang disusun hakim-hakim Amerika dalam berbagai putusan selama bertahun-tahun (Jonathan A. Marcantel, 2010,. hal.195). yang terkadang saling tumpang-tindih. Sebagai contoh, Pengadilan Tinggi California menyusun tak kurang dari 20 faktor yang dapat diacu dalam rangka menjustifikasi putusan PCV; penelitian Brown menunjukkan sebagian besar pengadilan di ke-50 negara bagian Amerika Serikat menggunakan 12 faktor (Jonathan A. Marcantel, 2010:197), Caudill mengatakan bahwa pembahasan dan diskursus hukum sering mengerucut ke tiga tipe legal test, yakni tes alter ego, instrumentality, dan keadilan; dan Presser mengatakan sebaliknya: bahwa terdapat sedikit sekali konsensus atau kesepakatan mengenai legal test, faktor, dan kategori mana yang paling baik/ utama/tepat.

Rasio di balik pengaturan PCV dalam common law Amerika adalah karena pendekatan presedens mampu menjamin kepastian hukum yang lebih stabil, predictable, dan efisien dalam jangka panjang (Giacomo A. M. Ponzetto
\& Patricio A. Fernandez, 2008,.hal. 411.) Dengan membiarkan PCV diatur dalam judge-made law atau common law, diharapkan rupa dan wujud doktrin PCV terbentuk secara evolusioner dan organik.

g. Aturan PCV dalam Undang-Undang Perseroan Republik Rakyat Cina

Walaupun prinsip pertanggungjawaban terbatas telah dikenal sejak 1994, doktrin PCV sendiri baru disisipkan dalam perubahan UUPT Cina di tahun 2006 (Mark Wu, 2007. hal. 329). Penyisipan aturan PCV ini merupakan yang pertama kali bagi Cina setelah selama lebih dari 100 tahun memiliki kodifikasi undang-undang di bidang perusahaan. Walaupun hukum perusahaan Cina telah banyak mengadopsi ketentuan hukum perusahaan dari negara barat, negara ini dikenal memiliki ideologi sosialisme yang sangat mewarnai ketentuan peraturan perundang-undangannya (Kirby menyebutnya 'kapitalisme dengan gaya Cina'(William C. Kirby, 1995: Vol. 43: 43-63).

Walaupun baru dikenal secara formal pada tahun 2006, Mahkamah Agung Cina sebenarnya telah beberapa kali mengeluarkan surat jawaban atas pertanyaan hakim-hakim tinggi (salah satunya adalah Pengadilan Tinggi Zhejiang, Guangdong, dan Jiangsu (Hui Huang: vol. 60, 2012, hal. 743774, hal. 770), yang berkaitan dengan PCV (Bradley C. Reed, 2006:16611662, . Hui Huang, 2012: 770, Mark Wu, 2007:331.) dan telah beberapa kali menguatkan putusan PCV pengadilan yang lebih rendah (Zhang Xianchu, 1996, Mark Wu, 2007:331). Jawabanjawaban yang diberikan Mahkamah Agung Cina (pada tahun 1994, 2001, dan 2003)memperlihatkan bahwa pengadilan Cina dapat mengabulkan permohonan melakukan PCV, namun hanya dalam situasi dan kondisi tertentu, dan bahwa penerapan PCV di Cina sendiri tidak konsisten David M. Albert, 2002: Vol.23:884). Surat jawaban ini tidak dapat ditafsirkan sebagai sumber hukum yang mengikat nasional, karena sifatnya yang merupakan jawaban atas 
pertanyaan konkret mengenai suatu kasus yang spesifik.

Langkah Cina mengodifikasikan suatu doktrin yang terkenal rumit dan nirbangun (Huang Hui, 2012:770) seperti PCV adalah langkah yang berani. Amerika sendiri sebagai negara yang telah ratusan tahun menerapkan doktrin PCV dan telah memiliki literatur PCV yang sangat kaya sendiri ternyata tidak pernah berupaya mengodifikasikan doktrin PCV ini ke dalam peraturan tertulis. Mengapa Cina, yang notabene baru secara formal mengenal pertanggungjawaban terbatas perusahaan pada tahun 1994, tiba-tiba memiliki UUPT Cina 2006 yang secara terang-benderang mencantumkan doktrin PCV dalam Pasal 20 dan 64-nya?

Berangkat dari proses pembentukan peraturan perundang-undangan di Cina tidak transparan dan peneliti menemui kesulitan ketika menghimpun sumbersumber resmi dari pemerintah Cina. Jadi hasil deduksi dalam penelitian ini sebagian besar bersandar pada laporan penelitian beberapa orang sarjana hukum dan bukan pada informasi atau pernyataan resmi pemerintah Cina, Kami menyimpulkan, bahwa model pengaturan yang seperti ini sangat terdorong oleh fakta bahwa Cina adalah negara penganut tradisi hukum civil law dan bahwa Cina memiliki ideologi sosialisme yang mengakar kuat. Sebagai negara civil law, Cina memiliki bias yang besar ke arah hukum positif dan peraturan perundang-undangan tertulis alih-alih ke arah yurisprudensi. Perlu diketahui bahwa putusan pengadilan di negeri Cina tidak memiliki nilai preseden. Menurut Lubman, sebagaimana dikutip oleh Reed, doktrin hukum di Cina secara tegas menolak konsep binding force of precedence dan putusan pengadilan paling jauh hanya dapat dianggap sebagai teladan atau contoh aplikasi, namun tidak boleh dianggap sebagai sumber hukum (Bradley C. Reed, 2006:1664.).

Selain itu, Cina memiliki sistem politik yang sentralistik di mana sistem peradilan berada di bawah pengawasan legislatif (Chris X. Lin, 2003: vol. 4: 275). dan hanya legislatif, Kongres
Rakyat Nasional, dan Dewan Negara yang memiliki kewenangan menafsirkan undang-undang. Pengadilan di Cina hanya memiliki kewenangan menerapkan fakta-fakta konkret (das Sein) kepada hukum (das Sollen), tidak lebih.

2. Penerapan $p c v$ dalam peraturan perundang-undangan yang terkait dengan Perseroan Terbatas.

a. Prinsip PCV dalam perundang-undangan Indonesia

1) KUHD

Dalam KUHD ketentuan tentang perseroan terbatas di atur dalam pasal 36 sampai dengan 55 , Buku Kesatu, Bab Ketiga Bagian Ketiga. Seharusnya ada dua pasal lagi, yaitu Pasal 57 dan 58, namun berdasarkan Staatsblad 1938 No. 276, dua pasal tersebut telah dihapus. Hal-hal yang diatur antara lain, syarat pendirian dan tata cara pendirian, permodalan dan saham perseroan, pengurus perseroan, tempat kedudukan perseroan dan jangka waktu berdirinya perseroan, pembubaran perseroan, laporan keuangan (laporang untung rugi) perseroan.

Dari 19 pasal terkait dengan ketentuan perseroan terbatas tersebut, tidak ada satu pasal pun yang menyingung keberadaan piercing the corporate veil dalam konteks pertanggungjawaban pemegang saham. Ketentuan Pasal 40 Ayat (2) KUHD menyebutkan, "para persero atau pemegang saham tersebut tidak bertanggungjawab untuk lebih dari pada jumlah penuh andil tersebut". Berbeda dengan UU PT, baik UU No. 1 Tahun 1995 maupun UU PT. No. 40 Tahun 2007, KUHD tidak memberikan pengecualian atas prinsip limited liability (pertanggungjawaban terbatas). Oleh karenanya, piercing the corporate veil dalam konteks pemagang saham tidak dikenal dalam ketentuan KUHD.

2) UU No. 1 Tahun 1995 tentang Perseroan Terbatas 
Dengan berlakunya UU No. 1 Tahun 1995 tentang Perseroan Terbatas yang mulai berlaku tanggal 7 Maret 1996, maka segala ketentuan dalam Buku Kesatu Bagian III Bagian Ketiga, Pasal 36 - 56 KUHD dinyatakan tidak berlaku lagi. Prinsip dasar limited liability ditegaskan dalam Pasal 3 Ayat (1) UU PT No. 1 Tahun 1995, yang menyebutkan bahwa, "pemegang saham perseroan tidak bertanggungjawab secara pribadi atas perikatan yang dibuat atas nama perseroan dan tidak bertanggungjawab atas kerugian perseroan melebihi nilai saham yang telah diambilnya". Namun demikian prinsip tersebut tidaklah berlaku mutlak, dimana Pasal 3 Ayat (2) UU No. 1 Tahun 1995 membuka ruang pertanggungjawaban pemegang saham melebihi saham yang ia setorkan apabila:

1. Persyaratan perseroan sebagai badan hukum belum atau tidak terpenuhi;

2. Pemegang saham yang bersangkutan baik langsung maupun tidak langsung dengan itikad buruk memanfaatkan perseroan semata-mata untuk kepentingan pribadi;

3. Pemegang saham yang bersangkutan terlibat dalam perbuatan melawan hukum yang dilakukan oleh perseroan; atau

4. Pemegang saham yang bersangkutan baik langsung maupun tidak langsung secara melawan hukum menggunakan kekayaan perseroan, yang mengakibatkan kekayaan perseroan menjadi tidak cukup untuk melunasi hutangnya.

3) UU No. 40 Tahun 2007 tentang Perseroan Terbatas

Sama halnya dengan UU PT No. 1 Tahun 1995, UU PT No. 40 Tahun 2007 sampai batas tertentu juga mengakui berlakunya teori piercing the corporate veil, dengan membebankan tanggungjawab tersebut kepada pihak-pihak sebagai berikut: (1) Beban tanggungjawab dipindahkan ke pihak pemegang saham; (2) Beban tanggungjawab dipindahkan ke pihak Direksi dan Dewan Komisaris. Pemindahan beban tanggungjawab kepada pemegang saham dalam UU PT No. 40 Tahun 2007 antara lain di atur dalam Pasal 33 Ayat (1) dan (2), Pasal 7 Ayat (5) dan (6), serta Pasal 33. Selain itu, penerapan piercing the corporate veil dapat dilihat juga dari ketentuan Pasal 7 Ayat (1) UU PT No. 40 Tahun 2007 yang menyebutkan bahwa, "perseroan didirikan oleh dua orang atau lebih dengan akta notaris yang dibuat dalam bahasa Indonesia". Selanjutnya, Pasal 7 Ayat (5) dan (6), yang menyatakan setelah perseroan memperoleh status sebagai badan hukum dan pemegang saham kurang dari dua orang, maka dalam jangka waktu paling lama 6 bulan terhitung sejak keadaan tersebut, pemegang saham yang bersangkutan wajib mengalihkan sebagian sahamnya kepada orang lain atau perseroan mengeluarkan saham baru kepada orang lain. Selanjutnya, dalam jangka waktu enam bulan tersebut, pemegang saham tetap kurang dari dua orang, pemegang saham bertanggungjawab secara pribadi atas segala perikatan dan kerugian perseroan, dan atas pihak yang berkepentingan Pengadilan Negeri dapat membubarkan perseroan tersebut.

Berdasarkan uraianuraian tersebut di atas, tampak terdapat perluasan pengaturan doktrinpiercing the corporate veil dari KUHD sampai dengan UU No. 1 Tahun 1995 dan UU No. 40 Tahun 2007. Sebagai produk kolonial Belanda yang dibuat tahun 1840 , KUHD belum mengatur doktrin piercing the corporate veil, khusus terkait dengan untuk pemegang saham. UU PT No. 1 Tahun 1995 sebagai pengganti ketentuan 
mengenai perseroan terbatas yang ada dalam KUHD, kemudian telah memasukkan ketentuan piercing the corporate veil terkait keberadaan pemegang saham dan memperluas ketentuan piercing the corporate veil yang berkaitan dengan Direksi dan Komisaris. UU No. 40 Tahun 2007 sebagai pengganti UU No. 1 Tahun 1995, secara prinsip tidak mengubah atau menambahkan materi atau bentuk pelanggaran piercing the corporate veil.

Apabila dirunut dari KUHD sampai dengan UU No. 40 Tahu 2007, dapat disimpulkan secara normatif perbuatan-perbuatan yang dapat dikategorikan sebagai piercing corporate veil, dalam hukum perseroan terbatas di Indonesia, antara lain:

1. Direksi melanggar Anggaran Dasar atau perubahan Anggaran Dasar perseroan;

2. Formalitas pendirian perseroan belum terpenuhi baik oleh Pemegang Saham;

3. Pemegang saham yang bersangkutan baik langsung maupun tidak langsung dengan itikad buruk memanfaatkan perseroan semata-mata untuk kepentingan pribadi;

4. Pemegang saham yang bersangkutan terlibat dalam perbuatan melawan hukum yang dilakukan oleh perseroan; atau

5. Pemegang saham yang bersangkutan baik langsung maupun tidak langsung secara melawan hukum menggunakan kekayaan perseroan, yang mengakibatkan kekayaan perseroan menjadi tidak cukup untuk melunasi hutangnya;

6. Perolehan saham melalui mekanisme pembelian saham kembali oleh perseroan yang tidak sesuai dengan ketentuan perundang-undangan,

7. Direksi dan atau Komisaris tidak melaksanakan fiduaciary duty;
8. Perhitungan laporan tahunan oleh Direksi dan atau Komisaris, khususnya laporan keuangan yang tidak benar atau menyesatkan;

9. Direksi dan atau merupakan penyebab perusahaan mengalami kepailitan.

b. Penerapan Prinsip PCV dalam kasus (praktek) di lapangan

Secara normatif ketentuan piercing the corporate veilbaru dilembagakan dalam undang-undang berdasarkan UU No. 1 Tahun 1995, mengingat KUHD sebagai warisan Kolonial Belanda belum mengatur doktrinpiercing corporate veil, khusus terkait dengan untuk pemegang saham. Namun dalam kasus PT. Bank Pembangunan Asia dengan PT. Djaya Tunggal di tahun 1991, prinsip tersebut telah dipakai oleh Hakim dalam pertimbangan hukumnya, meskipun belum ada dasar hukumnya secara normatif, kecuali dalam KUHD yang diatur secara terbatas. Dalam pertimbangan hukumnya, Hakim Mahkamah Agung telah menerapkan teori atau doktrin piercing the corporate veil, yaitu tindakan persekongkoln antara Direksi dan Dewan Komisaris, yang menyebabkan kerugian pada perusahaan, dapat diminta pertanggungjawaban terhadap Direksi dan Komisaris yang bersekongkol tersebut. Hal yang sama juga berlaku dalam kasus O. Sibarani dengan PT. Perusahaan Pelayaran Samudera "Gesuri Lloyd" tahun 1973 dimana Mahkamah Agung membuat hukum sendiri berdasarkan doktrinpiercing the corporate veil, yang kemudian subtansi putusan kemudian diadopsi dalam Pasal 7 Ayat (4) UU No. 1 Tahun 1995 dan diadopsi lagi dalam Pasal 7 Ayat (5) UU No. 40 Tahun 2007, yang menyatakan bahwa setelah perseroan memperoleh status badan hukum dan pemegang saham menjadi kurang dari 2 (dua) orang, maka pemegang saham bertanggungjawab secara pribadi apabila dalam jangka waktu paling lama 6 (enam) bulan tidak mengalihkan sebagian saham kepada pihak lain atau perseroan juga tidak mengeluarkan saham baru kepada orang lain. Hal 
yang sama juga diterapkan dalam PT. Usaha Sandang dengan PT. Dhaseng Ltd, PT. Interland Ltd. Sedikit berbeda dengan dalam kasus Raden Roosman dengan Perusahaan Otobis N.V. Sendiko dengan mendasarkan pada Pasal 39 selama prosedur pendirian perseroan belum terpenuhi maka pengurus yang menyebabkan kerugian perseroan yang belum berbadan hukum tersebut dapat dimintakan pertanggungjawaban.

Menjadi pertanyaan selanjutnya adalah apakah peng-normatifan doktrin piercing the corporate veil dalam undangundang bersifat efektif, khususnya Pasal 3 Ayat (2) UU No. 1 Tahun 1995 atau Pasal 3 Ayat (2) UU No 40 Tahun 2007? Atau apakah peng-normatifan tersebut menjadi sesuatu yang sangat diperlukan? Menjawab pertanyaan ini, berdasarkan pengalaman empiris dalam praktik, meskipun doktrin tersebut tidak diakomudasi (belum terakomodasi) dalam suatu undangundang, namun praktiknya Hakimdalam hal ini Mahkamah Agung-telah menggunakan sebagai dasar atau bahan pertimbangannya, sebagaimana terjadi dalam kasus PT. Bank Perkembangan Asia dengan PT. Djaja Tunggal, misalnya. Artinya, sebagai suatu doktrin piercing the corporate veil telah merasuk dalam praktik pengadilan Indonesia, tanpa perlu dinormatifkan dalam suatu bentuk peraturan terlebih dahulu. Namun, jika pun kemudian mengnormatifkan doktrin dalam suatu peraturan perundangundanganpun, menurut penulis juga tidak menjadi masalah. Meskipun sejauh pengamatan penulis sampai saat ini, penulis belum menemukan suatu kasus yang mendasarkan putusan berdasarkan ketentuan Pasal 3 Ayat (2) UU No. 1 Tahun 1995 atau Pasal 3 Ayat (2) UU No. 40 Tahun 2007.

\section{d. Simpulan}

1. Arti penting pengaturan PCV dalam peraturan perundang-undangan di bidang perseroan terbatas adalah karena: (1) PCV dalam common law tidak memiliki kepastian hukum, terlalu banyak menyenderkan diri pada diskresi hakim, dan mahal; (2) bila aturan PCV diperjelas melalui undang-undang, maka efek jera akan dapat tercapai karena ada sanksi yang tegas; (3) biaya litigasi dapat ditekan; dan (4) untuk memberikan 'sinyal hijau' bagi hakim-hakim Indonesia yang ber-mindset civil law supaya tidak enggan lagi mengabulkan permohonan PCV.

2. Dalam konteks normatif dalam peraturan perundang-undangan terkait dengan perseroan terbatas terdapat perluasan pengaturan prinsip PCV dari KUHD sampai dengan UU No. 1 Tahun 1995 dan UU No. 40 Tahun 2007. Sebagai produk kolonial Belanda yang dibuat tahun 1840, KUHD belum mengatur doktrinPCV, khusus terkait dengan pemegang saham. UU PT No. 1 Tahun 1995 sebagai pengganti ketentuan mengenai perseroan terbatas yang ada dalam KUHD, kemudian telah memasukkan ketentuan PCV terkait keberadaan pemegang saham dan memperluas ketentuan PCV yang berkaitan dengan Direksi dan Komisaris. UU No. 40 Tahun 2007 sebagai pengganti UU No. 1 Tahun 1995, secara prinsip tidak mengubah atau menambahkan materi atau bentuk pelanggaran PCV. 


\section{daftar Pustaka}

Anderson, Helen., 2009, "Piercing the Veil on Corporate Groups in Australia", Melbourne University Law review, 33.

Bradley C. Reed, "Clearing Away the Mist: Suggestions for Developing a Principled Veil Piercing Doctrine.

Cheng, Thomas K., 2011a, "The Corporate Veil Doctrine Revisited: A Comparative Study of the English and the U.S. Corporate Veil Doctrines", Boston college International and comparative Law review, 34(2).

Chris X. Lin, "A Quiet Revolution: An Overview of China's Judicial Reform", Asian-Pacific Law and Policy Journal, vol. 4, 2003.

Giacomo A. M. Ponzetto\& Patricio A. Fernandez, 2008.

Hui Huang, "Piercing the Corporate Veil in China: Where Is It Now and Where Is It Heading?", The American Journal of Comparative Law, vol. 60, 2012, hlm. 743-774.

Marcantel, Jonathan A. (2010), "Because Judges Are Not Angels Either: Limiting Judicial Discretion by Introducing Objectivity into Piercing Doctrine", Kansas Law review, 59, hal 191-230 dan Thompson.

Kurt A. Strasser, "Piercing the Veil in Corporate Groups", connecticut Law review, vol. 37, 2005.

Richard Posner, "The Rights of Creditors of Affiliated Corporations", University of chicago Law review, vol. 499, 1976, hlm. 520-521.

Reed, Bradley C. (2006). "Clearing Away the Mist: Suggestions for Developing a Principled Veil Piercing Doctrine in China", vanderbilt Journal of Transnational Law, 39.

Sulistiowati, 2010, Aspek Hukum dan Realitas Bisnis Perusahaan Grup di Indonesia, Jakarta: Erlangga

Thomas K. Cheng, "The Lifting of Corporate Veil Doctrine in Hong Kong: An Empirical, Comparative and Development Perspective", common Law World review, vol. 40, 2011.

Thompson, Robert B, (1991), "Piercing the Corporate Veil: An Empirical Study", cornell Law review, 76. 